Guro Nore Fløgstad og Helene Urdland Karlsen

\title{
Rettslingvistisk praksis i Norge
}

Et kritisk blikk på behandlingen av språkmaterialet i

Bertheussen-saken

\section{Forensic linguistic practice in Norway}

A critical examination of the treatment of language

material in the Bertheussen-case

Tidsskriftet Sakprosa

Bind 13, Nummer 3

(C) 2021

10.5617/sakprosa.8715 


\section{Sammendrag}

Hva er rettslingvistikk, og hvordan praktiseres denne formen for lingvistisk analyse i norsk politiarbeid og i det norske rettssystemet? I denne artikkelen tar vi utgangspunkt i hvordan språkmaterialet i Bertheussen-saken ble behandlet, og diskuterer hvordan kunnskapsbasert praksis innen rettslingvistikk kunne gitt denne behandlingen mer tyngde. Vi undersøker hvilke analysemetoder rettslingvistikken tilbyr, og fokuserer på språklig profilering og opphavsanalyse, og kommer med konkrete forslag til å utarbeide etiske retningslinjer for en rettslingvistisk praksis i Norge. Til slutt diskuterer vi språkets særstilling, i skjæringspunktet mellom kognitiv vitenskap og humaniora, og hvordan denne iboende tverrfagligheten påvirker rettslingvistikken som politimetode.

\section{Abstract}

What is forensic linguistics, and how is this form of linguistic analysis practiced in Norwegian police work and in the Norwegian legal system? In this article, we take as our starting point how the language material in the Bertheussen case was treated and discuss how knowledge-based practice in forensic linguistics could have given this treatment more weight. We investigate which analytic methods forensic linguistics offers, and focus on linguistic profiling and authorship analysis, and come up with concrete proposals to prepare ethical guidelines for a forensic linguistic practice in Norway. Finally, we discuss the special position of language, at the intersection of cognitive science and the humanities, and how this inherent interdisciplinarity affects forensic linguistics as a police method. 
Nøkkelord: anvendt lingvistikk; Bertheussen-saken; idiolekt; opphavsanalyse; profilering; rettslingvistikk; trusselbrev

Keywords: applied linguistics; authorship analysis; Bertheussen-case; forensic linguistic; idiolect; profiling; threats

\section{Om forfatterene:}

Guro Nore Fløgstad er førsteamanuensis i lingvistikk og norsk ved Universitetet i Sørøst-Norge, og har doktorgrad i lingvistikk fra Universitetet i Oslo. Hun forsker på språklig variasjon og endring i norsk, romani og romansk.

Helene Urdland Karlsen er master i nordisk språk og litteratur ved Universitet et i Bergen, og har bakgrunn som leksikograf. Hun arbeider til vanlig som seniorrådgiver i seksjonen for språk i skole og offentlig forvaltning i Språkrådet (NO).

Begge forfatterne har spesialisering i rettslingvistikk fra Hofstra University i USA. 


\section{Rettslingvistisk praksis i Norge. Et kritisk blikk på behandlingen av språkmaterialet i Bertheussen-saken}

Man trenger ikke være språkforsker for å se at språket er tilgjort. (Statsadvokat Marit Formo om språkmaterialet i Bertheussen-saken, 21. oktober 2020)

\section{Innledning: Tekst og trusler}

De siste årene har norsk offentlighet kunnet følge med på flere høyprofilerte straffesaker. Felles for de sakene som har fått aller størst oppmerksomhet i media, er det at de inneholder språk- eller tekstmateriale som blir knyttet til kriminelle aktiviteter. Som i samfunnet ellers har kommunikasjonen fra kriminelle blitt mer og mer tekstbasert (Christensen, 2019). Det har aldri vært lettere å komme med trusler og andre kriminelle ytringer.

Hva skjer egentlig med tekstmaterialet i norske straffesaker? Hvem analyserer det, og hvordan blir det behandlet? Et dykk ned i norske dommer avslører at det ikke er noen etablerte rutiner for behandlingen av denne typen bevismateriale i Norge. I Baneheia-saken, der to jenter ble drept i 200o, ble aldri språket i domfelte Viggo Kristiansens SMS-er analysert, selv om de fremdeles er å regne som hans sterkeste alibi. I narkotikasaken mot tidligere politimann Eirik Jensen var det Spesialenheten for politisaker som analyserte "blomsterspråket” i de kodede meldingene mellom Jensen og narkotika-smugleren Gjermund Cappelen. I saken mot den norske "IS-kvinnen" sto analyser av hennes meldinger sentralt i bevisførselen, uten at disse ble analysert av språkeksperter. Sistnevnte er spesielt forstemmende, da vi har særs gode verktøy for å fortolke akkurat slik kommunikasjon (se f.eks. Christensen 2021, om chattemateriale i rettssaker mot danske fremmedkrigere).

Mellom 2018 og 2021 var en annen sak i medias søkelys i Norge. Daværende justisminister Tor Mikkel Waras hus ble utsatt for hærverk, og han mottok 
trusler og rasistiske beskyldninger. Disse truslene ble i utgangspunktet forsøkt knyttet til teaterstykket Ways of seeing i regi av Pia Maria Roll, satt opp på Black Box Teater i Oslo. Teaterstykkets mål var blant annet å sette søkelys på den høyrevridde makteliten i Norge. Waras kone, Laila Bertheussen, var uttalt kritisk til stykket, og da truslene begynte å komme mot hennes mann og eiendom, forsøkte mange, herunder Bertheussen selv, å knytte truslene mot paret til teatret og radikale krefter på venstresiden. Kunstnerne bak stykket sto hardt på sitt: dette hadde ingenting med dem å gjøre. Og de fikk rett. I 2019 ble Bertheussen selv pågrepet av Politiets sikkerhetstjeneste (PST) og senere tiltalt for angrep på demokratiet gjennom brannstiftelse, skadeverk og trusler mot ledende politikere, herunder hennes egen samboer.

Da saken kom opp for retten i 2020, sto språklige bevis sentralt, og aktoratet i saken førte en språkekspert som vitne i straffesaken. De språklige detaljene fikk mye oppmerksomhet, det samme gjorde troverdigheten til ekspertvitnes analyser. Hendelsen skulle gjøre den språkvitenskaplige disiplinen rettslingvistikk kjent i norsk offentlighet. Men var det egentlig rettslingvistikk som ble praktisert i rettssal 250 høsten 2020 ?

Formålet med denne artikkelen er å belyse hvilke muligheter som ligger i en rettslingvistisk analyse. Rettslingvistikk er en form for anvendt lingvistikk, som primært har to ting fore: å bidra i etterforskning, i form av analyser av språklig materiale, og å belyse språk i rettssalen, gjennom skriftlige rapporter og lingvistiske ekspertvitner. Vi legger altså til grunn en bred forståelse av begrepet, som språk i en juridisk kontekst (se også Christensen \& Mortensen, 2018).

I denne artikkelen har vi særlig fokus på rettslingvistisk profilering og opphavsanalyse, og hvilken forskning som ligger til grunn for god praksis i dag. Grunnpremisset i rettslingvistisk profileringsarbeid er enkelt: skriftlige og muntlige data kan gi relevant informasjon om taler eller skriver. Språkbrukerens idiolekt, eller særegne språksystem (Sandøy, 1996) vil kunne 
avdekke informasjon om vedkommendes demografiske og sosiale bakgrunn, f.eks. alder, kjønn, utdanning, morsmål, geografisk opphav, politiske ståsted og religiøse overbevisning. En rettslingvistisk analyse vil likevel ikke kunne gi et entydig svar på hvem avsenderen er, oppsummert av Olsson (2018) slik: "At no stage does forensic linguistics ever claim to identify an author" (s. 21). Ofte vil avsenderen også ønske å skjule sin egen identitet ved å forkludre egen språkbruk.

Både idiolekt og forkludring var høyrelevant i Bertheussen-saken. Vi vil se kritisk på behandlingen av det språklige materialet i denne saken, både hva som ble gjort, og hvorvidt det finnes forskning som kunne gjort analysene enda grundigere. Til slutt vil vi oppsummere hvordan en slik faglig tilnærming vil være til nytte i politiarbeid, samt se dette i en større vitenskapelig kontekst, hvor lingvistikken befinner seg i skjæringspunktet mellom kognitiv vitenskap og humaniora.

Det er viktig å påpeke at avgjørelsen i Bertheussen-saken bygger på en hel rekke bevis, hvorav en språklig analyse av tekstmateriale bare utgjorde en del. Den kritikken som framlegges i denne artikkelen innebærer ingen stillingstaken til om dommen er riktig eller gal sett ut fra det samlede bevisbildet.

Bertheussen anket dommen på stedet da den ble lest opp i januar 2021, men Statsadvokaten anbefalte anken å nektes fremmet, og vurderte tingrettens dom som klar, velfundert og grundig. I juni 2021 bestemte Borgarting lagmannsrett å bare behandle Bertheussens anke over straffutmålingen. Skyldspørsmålet ble vurdert avgjort. Vi mener likevel at denne saken gir et godt utgangspunkt for en diskusjon om bruk av språklig materiale i juridisk sammenheng, og selv om dommen her var svært klar, vil slikt materiale kunne være viktig og potensielt avgjørende for utfallet i lignende saker. 


\section{Materiale og utvalg}

Grunnlaget for denne artikkelen er dokumenter som inngikk i saken, samt tingrettsdommen fra januar 2021. Språkmaterialet i Bertheussen-saken består av både trusler og det media har omtalt som tilståelsesbrev. I den første kategorien finner vi fire tilfeller av tagging på familien Waras husvegg og bil, og fire anonyme trusselbrev: tre sendt til familien Waras hus, ett sendt til familien Tybring-Gjeddes hus. Materialet i den andre kategorien består av flere anonyme brev og e-poster sendt til advokatkontoret Elden, NRK og Dagbladet etter pågripelsen av Laila Bertheussen. I de etterfølgende forsendelsene tar en aksjonsgruppe med inngående kjennskap til saken på seg skylden for ugjerningene i den første kategorien.

I artikkelen ser vi bare på språkmateriale der det foreligger fotostatiske kopier av originalene, frambrakt av politiet, en praksis som vi for øvrig diskuterer senere. Da vi ikke har fått tilgang til slike kopier av datamaterialet tilsendt NRK og Dagbladet, vil vi ikke kunne omtale språket i disse e-postene nærmere. Vi vil likevel kommentere enkelte av de språklige vurderingene gjort på bakgrunn av dette materialet. Påtalemyndighetens sakkyndige språkekspert var professor emeritus i nordisk språkvitenskap ved Universitetet i Agder, Sylfest Lomheim. Det bør nevnes at Lomheim kun vurderte språket i fire av de etterfølgende forsendelsene. 


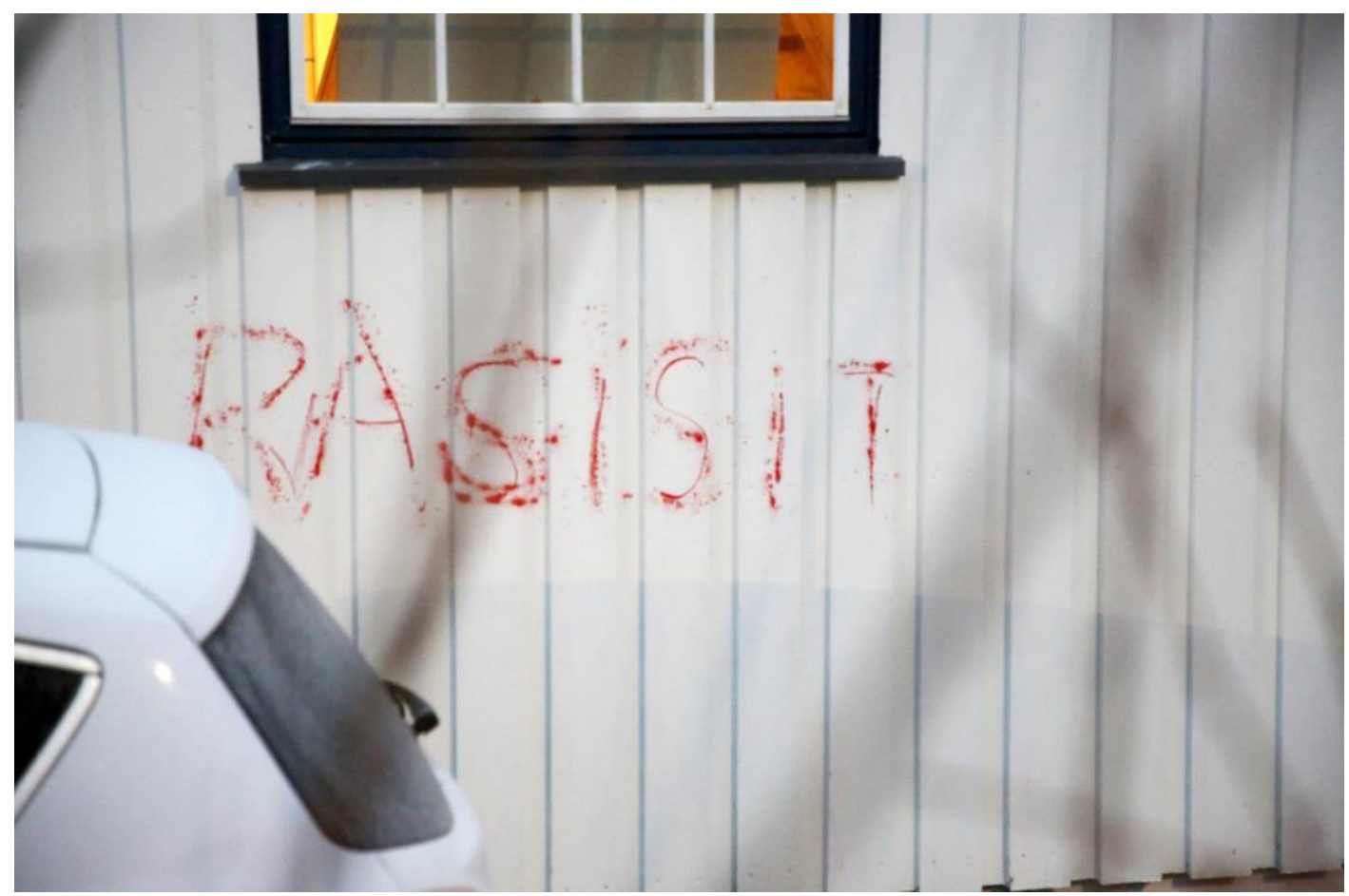

Tagging på familien Waras husvegg 6. desember 2018. Foto: Politiet/PST

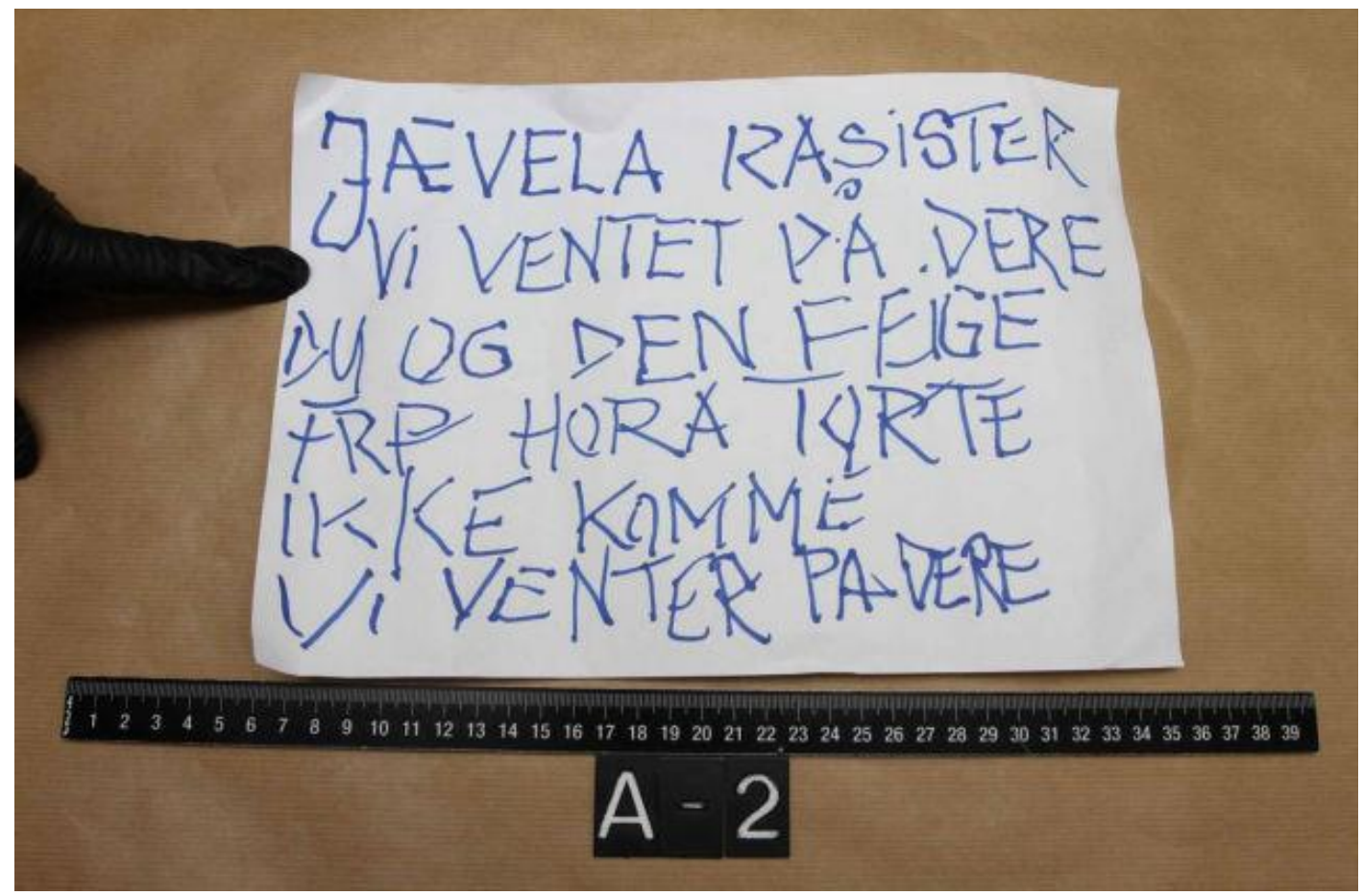

Trusselbrev i familien Waras postkasse 2. mars 2019. Foto: Politiet/PST

G. N. Fløgstad og H. U. Karlsen

$8 / 40$

Sakprosa.no 


\section{Rettslingvistikken som fag og metode}

\section{Faghistorie}

I slutten av november 1949 gikk Timothy John Evans inn på politistasjonen i Merthyr Tydfil, Wales, og erklærte at "I want to give myself up. I have disposed of my wife”. Det som fulgte, skulle markere begynnelsen på en helt ny forskningsdisiplin, takket være den svenske korpuslingvisten Jan Svartvik, og hans studie The Evans Statements: A Case For Forensic Linguistics (1968), utgitt på Gøteborg Universitets eget forlag nesten 20 år etter at ugjerningen hadde skjedd. Evans ble dømt til døden for drapene, men det viste seg noen år senere at det var hans nabo, John Reginald Halliday Christie, som hadde drept både Evans' kone og barn, i tillegg til en rekke andre kvinner. Svartvik fant ut at de lingvistiske trekkene i deler av Evans' "tilståelse" ikke kunne ha tilhørt en mann nærmest uten skolegang, som Evans var, og gjennom en grundig opphavsanalyse fant han forskjeller mellom avsnitt i teksten som tydet på at politiet måtte ha fabrikkert deler av tilståelsen.

Svartvik kalte sin analysemetode forensic linguistics, og metoden representerte en ny tilnærming til språklig analyse i politiarbeid. Svartvik var ikke alene på feltet i Sverige (se f.eks. Johannisson, 1973), men hans bidrag på engelsk løftet forskningen opp på et internasjonalt nivå. I forordet til teksten reflekterer Svartvik rundt den praktiske anvendelsen av språkvitenskapelig forskning. Disse refleksjonene illustrerer hvordan språkvitenskapen har utviklet seg - og samtidig stått på stedet hvil - det siste halve århundret. Først, skriver Svartvik, opplever han omsider at lingvistisk forskning har en direkte anvendelse, selv om han påpeker at slik anvendelse ikke skal være målet med all grunnforskning. En slik diskusjon om hva forskning skal brukes til, kan vi den dag i dag kjenne igjen fra pågående diskusjoner om profesjonsrettet forskning og grunnforskningens relevans. I tillegg diskuterer Svartvik hvordan Evans' tilståelse illustrerer det vi i dag ville kalle ulike sosioling- 
vistiske registre. Sosiolingvistikken var forsømt i forhold til andre språkvitenskapelige disipliner, mente Svartvik. Mye har skjedd i språkvitenskapen siden 1968, blant annet har sosiolingvistikken blitt likestilt med mer kognitivt orienterte tilnærminger til språk. Men det skulle imidlertid ta et par tiår før fagfeltet Svartvik selv introduserte - rettslingvistikken - virkelig skjøt fart. Sentralt i utviklingen sto arbeidene til den amerikanske rettslingvisten Robert Shuy, som ble publiserte sent på nittitallet og tidlig på totusentallet. I likhet med Svartvik hadde Shuy sin bakgrunn i anvendt lingvistikk, og hans forskningsproduksjon og tilstedeværelse i retten satte et avgjørende avtrykk på feltet.

Som påpekt innledningsvis, er rettslingvistikken i dag en omfattende disiplin. På makronivå er dette en vitenskap som i tillegg til anvendt lingvistikk knytter seg til juss og kriminologi. På mikronivå er det en vitenskap som krever bred språkkunnskap innen alt fra sosiolingvistikk, dialektologi, sjangerlære, korpuslingvistikk, flerspråklighet og psykolingvistikk. Kanskje særlig kunnskap om sosiolingvistisk variasjon er relevant. I tillegg er det relativt stor enighet om at man bør kombinere ulike metoder, i den forstand at rettslingvistiske analyser bør innebære en kombinasjon av kvantitativ (f.eks. korpuslingvistikk) og kvalitativ (f.eks. nærlesninger av tekst) metode.

\section{Rettslingvistikken i en norsk kontekst}

Norsk rettslingvistisk forskning er svært begrenset, og fagmiljøet er lite. Olsvik og Risan (2019:7) nevner at møter mellom ulike fagmiljøer har resultert i “økt kunnskap med høy relevans for etterforskningsprosessen”, og lister opp rettspsykologi, rettsmedisin, rettsfilosofi, og da også rettslingvistikk. MultiLing Senter for flerspråklighet ved Universitetet i Oslo har ledet prosjektet Formidling av rettigheter i politiavhør, som har et samtaleanalytisk fokus (se bl.a. Urbanik \& Pavlenko, i trykken). Universitetet i SørøstNorge er i ferd med å bygge opp et fagmiljø innen rettslingvistikk, og stipendiat der, Aafke Diepeveen, arbeider med en avhandling med fokus på 
språkbruk i avslutningsfasen av avhørssituasjonen, og hennes MA-oppgave omhandler en lignende tematikk (Diepeveen, 2020). Riis-Johansens doktoravhandling (2016) tar for seg avhør av voksne fornærmede, basert på lydopptak av avhør i Norge. Hjorths doktoravhandling (2019) undersøker tiltaltes talesituasjon i rettssalen. Denne avhandlingen er knyttet til et større prosjekt ved Universitetet i Bergen, som ser på fortellingens rolle i norske straffesaker ved hjelp av narrativ teori og analyse.

Når vi ser til den større nordiske konteksten, finnes det flere danske og svenske studier, bl.a. representert i et spesialnummer av Nordic Journal of Linguistics (2018), redigert av danske rettslingvister. At det er en spesiell interesse for rettslingvistikk i Norden er kanskje ikke overraskende, gitt at opphavet til selve begrepet er svensk. Samtidig er miljøet de nordiske landene i stor grad drevet av enkeltpersoner, slik som Tanya Karoli Christensen ved Københavns universitet, Sune Sønderberg Mortensen ved Roskilde Universitet, Gunilla Byrman ved Linnéuniversitetet i Växjö og Tarja SalmiTokonen ved Universitetet i Turku.

\section{Retningslinjer for det rettslingvistiske arbeidet}

En rettslingvistisk analyse nødvendiggjør refleksjon over og vurdering av en rekke faglige og etiske hensyn. Her diskuterer vi hvordan arbeidet bør utføres, og hva som kjennetegner god rettslingvistisk skikk. Vi undersøker også hvilket grunnlag som lå til grunn for språkarbeidet i Bertheussen-saken.

\section{Faglige retningslinjer}

I likhet med andre rettsvitenskaplige disipliner skal rettslingvistikken utøves på en måte som sikrer faglig integritet og objektivitet (IAFLL Code of Practice, 2013). Faglig integritet og objektivitet er, som vi skal se under, regnet for å 
være etiske prinsipper, som enhver rettslingvist bør etterstrebe. Prinsippene kan også sikres gjennom faglige retningslinjer eller vilkår for arbeidet.

Det er særlig ett vilkår som må oppfylles før en rettslingvistisk analyse kan finne sted. Tekstmaterialet som skal analyseres må være et originalmateriale eller en fotostatisk kopi av god kvalitet. Det er også ønskelig at tekstmaterialet legges fram på samme måte som det ble mottatt (dvs. at brev legges fram med eventuell konvolutt, e-post med avsender-, mottaker- og emnefelt) (Olsson, 2018). Dersom materialet er redigert (f.eks. av politiet eller media), kan det ikke analyseres for bruk i rettslig sammenheng, da det gir feilaktig informasjon om avsenderen. Dersom teksten er transkribert, må rettslingvisten få kjennskap til hvordan og etter hvilke regler arbeidet ble utført. Men det er viktig å være klar over at selv en profesjonell transkripsjon kan inneholde feil, og at noe så enkelt som feil gjengivelse av skilletegn kan påvirke den rettslingvistiske analysen. At media publiserer redigerte eller også transkriberte versjoner av trusselbrev o.l. er ikke uvanlig. De siste årene har det imidlertid blitt mer vanlig at media kontakter språkvitere for å få analysert slike versjoner, og at språkvitere også gjør dette uten forbehold om at versjonen ikke er original. Det var også tilfellet i Bertheussen-saken. Da påtalemyndighetens sakkyndige språkekspert inntok vitneboksen første gang 30. september 2020, kom det fram at han ble kontaktet av politiet først etter å ha analysert språkmateriale publisert i Dagbladet, og at han etter politiavhøret ikke hadde studert politiets originale språkmateriale særlig nøye, ei heller utferdiget en skriftlig rapport. Den skriftlige rapporten som ble lagt fram 16. oktober samme år kom først etter et krav fra forsvarsadvokat Elden.

Rettslingvisten bør videre - i den grad det er mulig - vite så lite som mulig om saken tekstmaterialet inngår i før og under analysearbeidet, dette for å sikre at ikke utenforliggende hensyn påvirker analysen og gjør rettslingvisten inhabil: «too much knowledge and you could contaminate the case» (Olsson, 2018:8). Selv en erfaren rettslingvist kan - om enn ubevisst - bli påvirket av det politiet, folk flest eller andre språkvitere mener om en sak i offentlige innspill. 
Den sakkyndige språkekspertens habilitet ble ikke så overraskende et tema under rettssaken mot Bertheussen. Forsvarsadvokat Elden forsøkte å stille spørsmålstegn ved språkekspertens habilitet, da han i avhør med politiet skal ha omtalt Waras kone, ved navns nevnelse, som mulig forfatter. For å forsøke å omgå dette problemet, og unngå subjektive fallgruver må både rettslingvisten og de som har engasjert rettslingvisten ha gode rutiner på plass.

Hva rettslingvisten har sett på av tekstmateriale, samt eventuelle faglige forbehold, bør alltid komme tydelig fram av analysen, eller aller helst nevnes i et arbeidsmandat. Et mandat kan også virke til å avklare forventninger. Som det er blitt pekt på tidligere, er det ikke slik at en rettslingvistisk analyse kan gi et entydig svar på hvem avsenderen av en tekst er. I mandatet bør det komme tydelig fram at analysen er som et hjelpemiddel å regne, ikke en fasit.

Forventningsavklaring er også relevant med tanke på oppdragsgiver. En rettslingvist arbeider ikke bare på oppdrag fra politi eller påtalemyndighet. Det er også vanlig at advokater engasjerer rettslingvister. For politi og påtalemyndighet stilles det særlige krav til objektivitet. I Norge er det alminnelige strafferettslige beviskravet uttrykt som «at enhver rimelig og fornuftig tvil skal komme den tiltalte til gode» (Rt. 2005, s. 1353). Det krever at politiet har en åpen tilnærming, også til et eventuelt språkmateriale som inngår i en straffesak. Advokaten på sin side, skal arbeide ensidig for sin klient. En slik partisk tilnærming hører ikke hjemme i rettslingvistikken (Ainsworth, 2009). Rettslingvisten er ikke og skal heller ikke opptre som en advokat, i overført betydning:

It is crucial for linguists to remain outside the advocacy that attorneys are [...] required to have. Linguists must carry out their analyses in such a way that the same result would occur if they were working for the other side. (Shuy, 2002:4) 
I Norge har politiet gode rutiner på å lage arbeidsmandat. Hva som stod i språkekspertens mandat er ikke offentlig kjent, og et åpenbart (og ubesvart) spørsmål er hvorvidt politiet og språkeksperten jobbet ut fra en åpen tilnærming til materialet. Det er alfa og omega at den rettslingvistiske analysen er objektiv og uavhengig av oppdragsgiveren. Det er retten som avgjør om analysen taler til fordel for den ene eller den andre siden i en rettssak (Olsson, 2018:6). Skyldspørsmålet angår ikke rettslingvisten.

\section{Etiske retningslinjer}

I land der rettslingvistikken står sterkt som fagdisiplin er det utviklet etiske retningslinjer for denne typen språkarbeid. De etiske retningslinjene har utspring i allmenngyldige etiske verdier og normer, men også etablerte forestillinger om god rettslingvistisk skikk.

The International Association for Forensic and Legal Linguistics (IAFLL) utviklet i 2013 en internasjonal standard: «Code of Practice». IAFLLs «Code of Practice» bygger på «Code of Ethics for Linguists in Forensic Linguistics Consulting», utarbeidet av etikkomiteen i The Linguistic Society of America i 2009. IAFLLs etiske retningslinjer er av overordnet karakter, og er ment å være generelle rettesnorer for medlemmer "who engage in forensic linguistic research and legal consulting and testimony.» (2013:1). I IAFLLs «Code of Practice» er fem etiske prinsipper listet opp: 1) Integrity, 2) Objectivity, 3) Professional Competency, 4) Confidentiality og 5) Conflict of Interest. Vi skal se nærmere på hva som ligger i disse begrepene.

Både faglig og personlig integritet er relevant her. Den rettslingvistiske analysen skal utføres på bakgrunn av faglig kompetanse og etablert forskningsbasert kunnskap og metode. Som vi var inne på over, innebærer det også at visse faglige vilkår for arbeidet blir oppfylt. Rettslingvisten skal jobbe uavhengig av oppdragsgivers standpunkt og ønsker, og uten tanke på egen (økonomisk) fordel og risiko. Rettslingvisten skal være og framstå som 
objektiv og saklig, rettferdig og upartisk. Det bør ikke, som i Bertheussensaken, kunne stilles spørsmål ved språkekspertens nøytralitet eller habilitet. Her forsøkte advokat Elden å diskreditere ekspertvitnet, først og fremst ved å ville tillegge vitnet forutinntatte meninger, men også ved å påpeke at vitnet hadde vært aktivt medlem av Arbeiderpartiet (og således politisk motstander av Wara som tilhører partiet FrP, ytre høyre fløy).

Språkvitere som tar på seg rettslingvistiske oppgaver må videre opptre ansvarlig i sin posisjon og i henhold til sin kompetanse. Det innebærer et ansvar for å forbedre og vedlikeholde faglige kunnskaper og ferdigheter, men også en forpliktelse til å takke nei til oppdrag som ligger utenfor ens egen fagkompetanse på det aktuelle tidspunktet. Like viktig er det at politiet reflekterer over hvem det er de henter inn til å gjøre slike analyser. Det må være noen med kjennskap til faget rettslingvistikk.

I behandlingen av et kriminelt språklig materiale vil rettslingvisten nødvendigvis måtte skrive under på en taushetserklæring. En rettslingvist må følgelig utvise diskresjon, og kan ikke uten videre diskutere eller dele konfidensiell informasjon om det som har kommet fram før, under eller etter analysearbeidet (Ainsworth, 2009). Dette av hensyn til saken, men også de involverte. Språkmaterialet er av særlig sensitiv karakter, og må behandles deretter. Personene som er involvert må også behandles med respekt. Heydon (2019) presiserer betydningen av å møte andre mennesker med hensyn og respekt, og at det er like avgjørende i sivile saker som i straffesaker. Det kan være lett å glemme at det er faktiske personer involvert, og at liv, rykte og framtid står på spill. For analysearbeidets del kan det innebære en mer eller mindre utstrakt bruk av anonymisering. I retten innebærer det at man som ekspertvitne opptrer på en taktfull måte.

Sist, men ikke minst, skal ikke en rettslingvist ta på seg oppdrag som kan resultere i noen form for interessekonflikt. En interessekonflikt kan til 
eksempel oppstå dersom en rettslingvist tar stilling til et skyldspørsmål (f.eks. i et intervju) etter å ha gjennomført en upartisk analyse.

\section{Utfordringer i en norsk kontekst}

Da rettslingvistikken ikke er etablert som fagdisiplin i Norge, finnes det heller ikke formulerte retningslinjer for praksisen. En konsekvens av dette er at det ikke tas hensyn til grunnleggende faglige vilkår for arbeidet, ei heller etiske prinsipper, som er avgjørende for å kunne ivareta grunnleggende rettssikkerhetsprinsipper.

Utvikling av norske retningslinjer vil kunne styrke tilliten til profesjonen, og gi den kredibilitet på lik linje med for eksempel skriftsgranskning eller rettsfonologi. Retningslinjene vil sikre at arbeidet blir utført på faglig korrekt måte, og at det er kvalifiserte fagpersoner som inntar vitneboksen som ekspertvitner. De media omtaler som «språkeksperter» har ikke nødvendigvis fagkunnskap innenfor rettslingvistikk. En særlig utfordring for rettslingvistikken, ikke bare her til lands, men også i utlandet, er at det er få som anerkjenner eller er klar over den kunnskapen en språkviter generelt eller en rettslingvist spesielt sitter på: «[...] most legal professionals either don't know what a linguist does, or think that, because they use language for a living, they are themselves experts in the subject.» (Heydon, 2019:1). Statsadvokat Marit Formos uttalelse om at man ikke trenger være språkforsker for å se at språket i de etterfølgende forsendelsene er tilgjort, bekrefter det. Resultatet er et rettsapparat med aktører (politi, advokater og tilfeldige «språkeksperter») «that [...] are unwittingly making decisions that are outside their area of expertise» (Heydon, 2019:2). Vi vender tilbake til denne utfordringen mot slutten av artikkelen.

Det finnes ulike verktøy for å formalisere disse retningslinjene. IAFLLs «Code of Practice» kan brukes som en rettesnor for det rettslingvistiske arbeidet, men også danne grunnlag for en diskusjon rundt hvilke faglige og etiske 
retningslinjer som skal ligge til grunn for rettslingvistisk arbeid i en norsk kontekst. Med disse retningslinjene i bakhodet skal vi nå gå gjennom hvilke verktøy som finnes for å systematisk angripe et språklig materiale analytisk.

\section{Lingvistisk profilering - systematisk avdekking av demografiske og sosiale faktorer}

Kjernen i vurderingen av språkmaterialet i Bertheussen-saken var å beskrive språket til den eller de antatte skriverne, og deretter gjøre antakelser om vedkommende på grunnlag av språklige trekk. Det er denne rettslingvistiske profileringen som på sett og vis er rettslingvistikkens kjerneområde, grundig beskrevet i forskningen (se f.eks. Chaski, 2013; McMenamin, 2002; Nini, 2015; Schilling \& Marsters, 2015; Shuy, 2014). Begrepet har faktisk en presedens helt tilbake til det gamle testamentet, hvor de gieladittiske soldatene ved elva Jordan drepte de som ønsket å krysse som uttalte ordet shibboleth på en måte som avslørte deres efraimittiske opphav. Den lingvistiske profileringen skiller seg fra f.eks. psykologisk profilering i at den førstnevnte tar utgangspunkt i rene språklige trekk, mens sistnevnte baserer seg på de psykologiske profilene til tidligere, kjente gjerningspersoner, og sammenligner disse.

Det overordnede spørsmålet i rettslingvistisk profilering er i bunn og grunn enkelt: finnes et lingvistisk fingeravtrykk? Her er det forskningsbaserte svaret entydig: "A linguistic profile does not claim to identify specific authors" (Shuy 2014:5). Det betyr imidlertid ikke at språket ikke kan avsløre en hel del om skriverens alder, kjønn, språklige bakgrunn, utdanningsnivå, og sosioøkonomiske status, selv om "fingeravtrykk" i og for seg ikke er en spesielt god metafor i og med at språket, i motsetning til fingeravtrykket, kan endres. 
Faktisk har profileringsarbeid vært avgjørende i etterforskning, og i å begrense antall mistenkte. Verdens kanskje mest kjente profileringssak er Unabomber-saken. Den nå legendariske rettslingvisten Roger Shuy ble på nittitallet bedt om å analysere et langt manifest som inneholdt konkrete trusler, etter at en inntil da uidentifisert person hadde sendt bomber og brev til avisredaksjoner, akademikere og flyselskaper i en årrekke. Manifestets lengde var i seg selv en fordel, gitt at 56 sider nødvendigvis vil inneholde en rekke lingvistiske, potensielt avslørende trekk (se for øvrig Stamatatos 2009 om tekstlengde). Det bør nevnes at manifestet først ble sendt til en rekke universitetsprofessorer, $\mathrm{i}$ håp om at de kunne gjenkjenne en tidligere student bak teksten. Men dette ikke veldig målrettede initiativet bar ikke frukter. Shuy, derimot, merket seg både leksikalske og grammatiske trekk som tillot ham å gjøre antakelser om skriverens alder, kjønn, geografiske tilhørighet, religion og utdanningsnivå. Disse skilte seg ganske radikalt fra den psykologiske profileringen som var blitt gjennomført, hvor gjerningspersonen ble antatt å være ung og lavt utdannet. Tvert imot påpekte Shuy at teksten var velskrevet, men stilistisk ulik humanistiske tekster. Dermed konkluderte Shuy med at skriveren hadde høy utdanning fra "the hard sciences", og en rekke andre ord, syntaktiske konstruksjoner og skrivefeil ga indikasjoner om at dette var en voksen, religiøs mann. Shuy pekte ikke ut gjerningspersonen, Ted Kaczynski (det gjorde faktisk broren hans, som gjenkjente tankegods i manifestet). Men analysen var avgjørende i etterforskningen, og begrenset antallet mistenkte i et for øvrig uoversiktlig landskap av 300 millioner mennesker.

Som regel er rettslingvistens arbeid langt enklere. Profileringsarbeid skjer ofte med utgangspunkt i en begrenset mengde mistenkte, eller, det kan dreie seg om å vurdere hvorvidt en tekst er skrevet av en allerede kjent person; såkalt opphavsanalyse. 
Opphavsanalysen skiller seg fra profilering ved at den sammenligner et språkmateriale av ukjent opphav med tekst produsert av en identifisert person, eller et begrenset antall mistenkte. Selv om dette var en åpenbar tilnærming til språkmaterialet i Bertheussen-saken, kan vi, basert på de dokumentene vi har undersøkt, konkludere med at denne typen analyse ikke ble gjennomført. Det er oppsiktsvekkende. Det sier seg selv at opphavsanalyse ville vært høyrelevant i Bertheussen-saken, da politiet mistenkte Berhteussen for ugjerningen allerede før språkeksperten var inne i bildet, og enkelt kunne sammenlignet språkmaterialet med hennes tidligere skrifter. Hvorfor brukte ikke aktoratet en slik tilnærming, kombinert med profilering og grundige korpussøk?

Opphavsanalysen har vært gjenstand for store teoretiske og metodologiske debatter de siste tiårene, med en tydelig opposisjon mellom to metodiske tilnærminger, en stilistisk og en kognitiv (McMenamin, 2010; Chaski, 2013; Nini \& Grant, 2013). Den stilistiske, eller variasjonistiske, tilnærmingen til opphavsanalyse angriper teksten med utgangspunkt i språklige trekk, som igjen er påvirket av sosio-historiske faktorer, og vil metodisk sammenligne tekster, eventuelt med supplerende korpusundersøkelser. En kognitiv tilnærming, på den annen side, vil ta utgangspunkt i et sett syntaktiske strukturer, men gå kvantitativt til verks, ved hjelp av statistiske modeller og automatiserte analytiske verktøy, for å vurdere forskjellene mellom tekster, og hvis de finnes, anta at disse reflekterer kognitive forskjeller mellom talere. Trolig er det mer fruktbart å kombinere disse metodiske tilnærmingene, og forankre dem i lingvistisk teori. Et forslag som har blitt formulert er å bruke systemisk funksjonell lingvistikk, kombinert med korpussøk (Nini \& Grant, 2013). Velutviklete metoder for opphavsanalyse vil kunne øke "etterprøvbarheten" til rettslingvistikken, og bidra til mer aksept for denne som vitenskapelig gyldig tilnærming. 


\section{POMIC: Å bruke språket for å legge skyld et annet sted}

En opphavsanalyse kan også være med på å avklare formålet med, altså selve motivet for, en tekst. Spørsmålet om motiv er særlig interessant i saker der det foreligger ett eller flere tilståelsesbrev i etterkant av en pågripelse, slik det gjør i Bertheussen-saken. Hva er det avsenderen eller avsenderne av disse ønsker å oppnå? Er motivet anger, og tilståelsen reell? Eller er motivet et ganske annet?

Selv om tilståelsesbrev kan være reelle (som i brevet i rådmannsaken i Bergen fra 1900-tallet, som advokat Elden trakk fram under prosedyren i Bertheussen-saken), viser opphavsanalyser fra USA imidlertid at reelle tilståelsesbrev er svært sjelden vare (Fitzgerald, 2007).

På bakgrunn av analyser av lignende brev i høyprofilerte saker, lanserte FBIs Behavioral Analysis Unit-1 (BAU-1) begrepet Post-offence manipulation of investigation communication (POMIC). Motivet bak denne typen kommunikasjon er ikke anger, men å avlede eller forvirre politiet ved å legge skyld et annet sted:

Invariably anonymous, POMICs assert that the person publicly accused, under investigation, in custody, or standing trial for a certain crime is innocent. The author usually claims responsibility for the crime or knows the "real" offender who always remains unnamed (Fitzgerald, 2007:8).

Et særlig brukt grep er å blande falsk informasjon med informasjon som bare en gjerningsperson kan kjenne til (Leonard et al., 2017). I de fleste tilfellene er tilståelsesbrevet eller -brevene forfattet av den siktede selv, eller av noen som står den siktede nær (Fitzgerald, 2007).

En av de mer kjente POMIC-sakene i USA, er den såkalte Hummert-saken fra 2004, der en selverklært seriemorder tok på seg drapet av Charlene Hummert, etter at ektemannen Brian Hummert ble siktet. I et brev gav seriemorderen fra 
seg inngående og presise detaljer om hvordan offeret i saken ble drept, og kom samtidig med «rettelser» for å bygge opp under en påstand om at det var han som drepte Charlene Hummert, ikke ektemannen. Den selverklærte seriemorderen skreiv blant annet at Charlene Hummert ble kvalt, noe som stemte, men med "a white nylon rope", ikke familiens røde hundehalsbånd, som politiet mente var drapsvåpenet. Ved hjelp av en opphavsanalyse avdekket rettslingvist Robert A. Leonard at brevet var en POMIC, skrevet av ektemannen selv.

Da det ikke er gjennomført opphavsanalyser i Bertheussen-saken, er det vanskelig å si om Bertheussen selv (eller noen andre) kan stå bak de senere anonyme forsendelsene, de såkalte tilståelsesbrevene, sendt til advokat Elden, NRK og Dagbladet, samt hva motivet for disse brevene egentlig er. Som i Hummert-saken bruker avsenderen eller avsenderne inngående kunnskap om saken (f.eks. urin på enkelte brev og bruk av Nozinan) for å bygge opp troverdighet i sin argumentasjon for at det er "vi” som står bak, ikke Bertheussen. Det legges også fram ny og konkret informasjon (f.eks. klokkeslett), derav informasjon som beviselig ikke stemmer (f.eks. tusj kastet i ventil).

\section{Lingvistiske ledetråder}

Profilering, i bred forstand, innebærer ulike former for språklig analyse. Rettslingvisten ser etter lingvistisk variasjon og stilmarkører, og jobber for å identifisere påfallende eller tilsynelatende uvanlig språkbruk i tekstmaterialet. Språklig evidens er såpass nyttig siden språklige trekk gjerne produseres ubevisst: «the observable results of the habitual and usually unconscious choices an author makes in the process of writing» (McMenamin 2010: 488, vår utheving). Skriveren kan også forkludre arbeidet bevisst i et forsøk på å skjule identitet eller rette oppmerksomheten mot andre. Alle profileringssaker krever en inngående lingvistisk kompetanse. Analytikeren må både avsløre de 
trekkene som kanskje brukes for å villede, samt bruke disse for å si noe om skriverens egentlige språkprofil og metalingvistiske kompetanse, det vil si vedkommendes kunnskap om språket for å lykkes i å manipulere det.

Det er helt avgjørende for lingvisten å være trent i å observere selv de minste detaljer, og alle deler av en tekst er relevante. Alle språklige nivåer må også undersøkes, det være seg ortografi, grammatikk, ordforråd og idiomatiske uttrykk og konstruksjoner. Det er utvilsomt slik at ulike lingvistiske analysenivåer gir ulik grad av pålitelig informasjon. Syntaks antas f.eks. å være mer pålitelig enn leksikon, fordi det krever større metaspråklig bevissthet for å manipulere slike konstruksjoner, og kjenne til hvilke konstruksjoner som varierer. Enkeltord, derimot, er mer mottakelige for manipulasjon (Juola, 2012; Marko, 2018). En persons ordforråd er også mer tilbøyelige til å endre seg i løpet av livsløpet enn grammatiske strukturer.

Uavhengig av hva slags profileringsarbeid en rettslingvist utfører, vil analyse av ulike språklige elementer alltid spille en rolle. Under beskriver vi ulike lingvistiske faktorer som var relevante i Bertheussen-saken, og som spiller en rolle i all rettslingvistisk profilering.

\section{Språkkompetanse}

Hva kjennetegner en morsmålsbruker? Hva kjennetegner en tekst skrevet av en innlærer? Et spørsmål som svært ofte dukker opp i lingvistisk profileringsarbeid, er hvorvidt skriveren er morsmålstaler, eller har et gitt språk, her norsk, som andrespråk. Slike spørsmål har blitt diskutert ikke bare i Bertheussen-saken, men også i den pågående Lørenskog-saken, og det ble også konkludert med at forsøket på å framstå som en innlærer i førstnevnte var nettopp det: et forsøk på lingvistisk utkledning. I Bertheussen-saken var den sakkyndige språkeksperten "10o prosent sikker” på at morsmålet til avsenderen er norsk, slik det er gjengitt i tingrettsdommen. 
Hva kjennetegner egentlig skriftspråket til en som skriver på et andrespråk? Den enorme forskningsproduksjonen innenfor flerspråklighet, mellomspråksanalyse, andrespråkslæring og nærliggende felt, er av åpenbar nytte her. Som en generalisering kan vi si at de feilene en innlærer gjør på andrespråket er påvirket av to ting: overføring fra førstespråket, på den ene siden; og markerte, altså spesielt vanskelige, trekk i målspråket, her norsk, på den andre siden. Dessuten må vi skille mellom feil som gjøres på grunn av skriftspråkets natur, og de som gjøres på grunn av det som er vanskelig i talespråket. Vanlige overføringer i skriftspråket er samskriving (JegEr), mens utbredte feil som gjøres på grunn av vanskeligheter med talespråket er vokalfeil (sikle i stedet for sykle, osv.).

Feil gjøres på både ordnivå og setningsnivå. Hva angår vokabular, brukte språkeksperten dette eksplisitt i sitt vitneutsagn i Bertheussen-saken, og påpekte at ordet takrenne eksemplifiserte en leksikalsk spesifikasjon som innlærere sjelden vil inneha. Det stemmer at innlærere tidlig i innlæringsfasen gjerne bruker flere overordnede ord (hyperonymer framfor hyponymer) og at takrenne ikke er et slikt ord, og dermed ikke et ord som forventes brukt av en innlærer.

Det er likevel vedkommendes metaspråklige kompetanse i norsk, som vil avgjøre hvor “vellykket” forsøket på å framstå som andrespråksbruker blir. Hvis vedkommende har liten kjennskap til hva som er vanskelig i norsk, vil hen f.eks. generere feil knyttet til spesielle bokstaver i norsk (ø, æ, å), droppe bøyingsformer, og bruke tilsynelatende enkle konstruksjoner og omskrivinger, for å unngå fremmedord. Det er imidlertid andre trekk som kjennetegner en andrespråkstekst i større grad, slik som avvikende plassering av negasjon og verbal i leddsetninger, samt problemer med dobbelt konsonant for å uttrykke vokallengde. Rettslingvisten har med andre ord en rekke verktøy for å avgjøre om en tekst er skrevet av en som har norsk som andrespråk, eller en som utgir 
seg for å ha norsk som andrespråk. Slik språklig utkledning skal vi se mer på nå.

\section{Genuinitet og språklig utkledning}

Når vi står overfor en tekst av ukjent opphav, er det første rettslingvisten må gjøre å undersøke om den synes å være genuin - altså skrevet av den eller de som hevder å være avsenderen eller avsenderne. For å rette oppmerksomheten mot andre, eller for å ikke bli avslørt, vil en person som f.eks. truer en annen gjennom brev osv. ofte manipulere språket sitt i et forsøk på å villede. Disse formene for manipulering kommer i ulike typer, bl.a. “innvandrerspråk”, ulike feiltyper assosiert med ulike sosiale klasser osv. Alt i alt, og kanskje heldigvis, er det svært krevende å lykkes med manipulering og utkledning, fordi det krever kunnskap om egen grammatikk, om den tiltenkte avsenders grammatikk og om sjangeren teksten skal skrives i.

Her vil analytikeren kunne stå overfor en dobbelt utfordring. Vedkommende må både avgjøre om språket er manipulert, og samtidig forsøke å innsnevre avsenders demografiske profil. Førstnevnte er gjerne enklere enn sistnevnte (Juola, 2012). De språklige trekkene man observerer vil representere språkvalg, ofte ubevisste sådan. Men i spørsmålet om genuinitet, må vi undersøke andre aspekter ved teksten, for eksempel dens koherens, samt ta høyde for at manipulerende språktrekk er valgt mer bevisst Det er likevel svært krevende å klare å opprettholde systematikken i feilene gjennom en hel tekst, og slike manipulerte tekster vil typisk inneha en del variasjon av ulik art, herunder knyttet til standardformer og dialektvalg.

Et spørsmål som gjør seg gjeldene her, er om teksten kan være oversatt elektronisk. En oversettelse fra Google Translate eller lignende vil være avgrenset til ett språk og generelt inneholde få språklige feil. I Bertheussensaken er storparten av tekstmaterialet språklig sett for dårlig til å være et 
resultat av en slik oversettelse, som ikke bare gir korrekt staving, men også god kongruens og korrekte bøyingsendelser. I en av de etterfølgende forsendelsene, sendt til Elden 14. mai 2019, finner man til eksempel denne setningen: “VI LØPE BAK HUS KASTE MARKER INN VENTIL”. Det er selvsagt mulig at deler av tekstmaterialet kan være elektronisk oversatt. Men tekstmaterialet som helhet vitner ikke om det, noe den sakkyndige språkeksperten også konkluderte med i retten.

\section{Én eller flere avsendere?}

Språket kan også gi informasjon om hvorvidt tekstmaterialet synes å være skrevet av én eller flere personer. Spørsmålet om antall gjerningspersoner kan være avgjørende, ikke bare i etterforskningsprosessen, men òg i en eventuell rettssak.

Spørsmålet om antall gjerningspersoner er særlig av interesse dersom et trusselbrev eller lignende inneholder pronomenet «vi». At pronomenet «vi» og ikke «jeg» eller “eg” blir brukt, er ikke grunnlag alene for å hevde at det er flere personer involvert. Den aktuelle teksten kan være skrevet av én eller flere som tilhører en faktisk gruppe, eller av én person alene som skjuler seg bak en påstått gruppe (se f.eks. Simons \& Tunkel, 2014).

Mens systematiske likheter i språket kan peke mot én skriver, kan systematiske ulikheter i språket, særlig på setnings-, avsnitt- eller tekstnivå indikere flere skrivere. Ulikheter i et sammensatt tekstmateriale kan også indikere ulike avsendere (f.eks. én eller flere copycater), som av ulik grunn (dog ofte økonomisk) tar del i samtalen. Likheter og ulikheter kan vise seg i mer eller mindre ubevisste valg av bestemte ord (f.eks. «Hei» eller «Hallo» i åpningen av et brev, en e-post e.l.), varianter (f.eks. «fler», «flere» eller «fleire») og bøyingsmønster (f.eks. «skjøt», «skøyt» eller «skaut»), og tegnsetning. Noe så enkelt som kommabruk kan brukes for å skille to skrivere eller to ulike avsendere fra hverandre (se f.eks. Grant, 2012). Datoangivelser (f.eks. 
“07.03.21", "7.3.21", "7/3-21” og “7/3/21"), tidsangivelser (f.eks. "0905”, “09.05” og “09:05”) med mer, kan også være en kilde til stor potensiell intraog intertalervariasjon. Et uttrykk som inngikk i Bertheussen-saken (dog ikke i språkekspertens analyse) var det hverdagslige "Vi ses" skrevet på et av trusselbrevene til Wara-familien. Dette er et godt eksempel på et uttrykk hvor man gjerne vil finne variasjon, for eksempel mellom bruk av "Vi sees" og "Vi ses”, som igjen kan være en typisk indikator på individuelle trekk. Veksling mellom ulike dialektale trekk eller språk (såkalt «kodeveksling») kan også indikere ulike avsendere. Fravær av variasjon kan ofte indikere at vi har med én skriver å gøøre, mens intratekstuell variasjon (f.eks. "RASIST" og "RASISIT") kan tyde på enten flere skrivere, eller bevisst manipulering av teksten.

Det at et språkmateriale ser ut til å ha ulike avsendere, kan også skyldes utenomspråklige faktorer, noe man må være klar over. En tekst skrevet i all hast vil gjerne inneholde flere skrivefeil enn en tekst det er jobbet lenge med. Tema og sjanger kan også påvirke språkbruken. Et trusselbrev vil formodentlig se annerledes ut enn et tilståelsesbrev.

I Bertheussen-materialet blir pronomenet «vi» brukt både i truslene ( «får VI det til» og «VI VENTER PÅ DERE») og i de etterfølgende forsendelsene (f.eks. «VI ISENESATE ALT» og «We were in house»). Da påtalemyndighetens språkkyndige ekspert bare undersøkte språket i den siste kategorien, ble ikke forekomstene av pronomenet «vi» i truslene problematisert. Det ble heller ikke undersøkt språklig om vi-et i truslene kunne tenkes å være det samme viet som i de senere brevene. Når retten konkluderte med at det språklige materialet i Bertheussen-saken (altså truslene og de etterfølgende forsendelsene) var skrevet av én og samme person, baserte det seg på analyser av skrift, konvolutter, ark og frimerker, samt innholdslikheter brevene imellom. Det at skriftgranskerne ikke kunne si noe sikkert om taggingen 6. desember 2018, og det at enkeltkonvolutter beviselig måtte være adressert eller postet av noen andre enn Bertheussen selv, fikk ikke noen betydning for tingrettsdommen. 
I sin analyse av de etterfølgende forsendelsene viser ikke den sakkyndige språkeksperten til språklige likheter og ulikheter utover det han mener er gjennomgående «ville og fantasifulle formuleringer» (TOSLO-2020-20518-2). At flere tekster er skrevet helt eller delvis på engelsk, kommenteres ikke i denne sammenhengen. Språkeksperten kan ikke si at det er samme person som har skrevet tekstene, men at det er en person med samme temperament og personlighetstype (NRK, 2020).

\section{Kjønn}

I rettssaken mot Bertheussen var kjønn det temaet som fikk størst oppmerksomhet, da påtalemyndighetens språkkyndige ekspert inntok vitneboksen. Sett fra et språkfaglig ståsted var ikke det så overraskende. Kjønn er og har vært et svært omdiskutert tema innenfor språkforskningen. Selv om språkforskere flest er enige i at kvinner og menn gjør ulike lingvistiske valg når de skriver og snakker, er det uenighet om hvorvidt det er mulig å si noe bestemt om et individs kjønn på bakgrunn av språklige belegg, da kjønn ikke er en konstant kategori. Hva som oppfattes som kvinnelig og mannlig kan variere alt etter hvordan et gitt samfunn definerer kjønn og kjønnets egenskaper.

I sosiolingvistikken ble både biologisk kjønn (sex) og kulturelt kjønn (gender) først behandlet som binære kategorier. Forskning på språk og kjønn viste blant annet at kvinner som regel brukte flere standardnære former (eller prestisjeformer) enn menn. Kvinnene synes å ha en mer forfinet og sofistikert språkbruk (Lakoff, 1975; Trudgill, 1972). William Labov (1990) skulle senere problematisere disse funnene, da hans forskning avdekket at kvinner på samme tid adopterte innovative og ikke-standardiserte former hyppigere enn menn. Labovs kjønnsparadoks viste at kvinners (og menns) språkbruk ikke var konstant. Med årene fikk betydningen av det sosiale og kulturelle aspektet ved kjønn stadig større anerkjennelse, og den klassiske forståelsen av kjønn 
som enten «mann» eller «kvinne» ble utfordret. I dag betraktes kjønn (gender) som noe som skapes og gjenskapes gjennom sosiale handlinger; kjønn er ikke bare noe vi er, men også noe vi gjør (West \& Zimmermann, 1987).

Påtalemyndighetens språkekspert argumenterte tidlig for at avsenderen av de såkalte tilståelsesbrevene trolig var en kvinne. Konklusjonen baserte seg på et helhetsinntrykk, men det var særlig bruken av verbet «tisse» i brevet til advokat Elden 14. mai 2019 som gjorde den språkkyndige eksperten sikker i sin sak: «Menn bruker ikkje den slags ord, med unntak av når dei snakkar til barn i familiære situasjonar eller til elevar i småskulen. Ein mann ville garantert ha valt eit tøffare ord i ein trusseltekst.» (TOSLO-2020-20518-2). Språkeksperten hentet selv fram ordet «pisse» som et mer sannsynlig leksikalsk valg, og påstod at menn generelt har en røffere og hardere språkbruk enn kvinner. En av tingrettsdommerne utfordret det sakkyndige vitnet og spurte om teksten ikke kunne vært skrevet av en feminin mann. Dette kunne ikke språkeksperten svare på. Han ble i etterkant også utfordret av fagfeller, som etterlyste både empiri og sammenligningsgrunnlag. Med et enkelt korpussøk kunne språkforsker Helene Uri vise at verbet «tisse» også blir brukt av menn i andre situasjoner (Vedeler, 2020).

At menn har en grovere språkbruk enn kvinner er kanskje en påstand Lakoff og Trudgill kunne ha stilt seg bak på 70-tallet. Nyere korpusbasert forskning på kjønn og banning viser imidlertid at kjønnsforskjellene er i ferd med å forsvinne, og at påstanden skissert over i stor grad er en stereotypi (Baker, 2014; Gauthier \& Guille, 2017). Gauthier og Guilles undersøkelser av twittermeldinger viser at noen banneord forekommer hyppigere hos de ulike kjønnene, men at «the majority of the swear words considered did not show significant gendered differences in representation» (2017:157). På grunnlag av nyere forskning er det grunn til å stille spørsmål ved den språkkyndige konklusjonen. Det er også verdt å merke seg at det i tilståelsesbrevene språkeksperten analyserte også forekom røff og hard ordbruk, som for 
eksempel «FRP SVINA», «SO FUCKING SORRY» og «on the way to hell». Disse forekomstene ble ikke behandlet. Under rettssaken ble det heller ikke reflektert rundt bruken av ordet «dog piss» i brevet til Dagbladet (2019), eller den grove språkbruken («JÆVELA RASISTER» og «FRP HORA») i brevet funnet i Wara-familiens postkasse 2. mars 2019.

Innenfor rettslingvistikken - og da særlig studier knyttet til språklig profilering - har kunnskapen om språk og kjønn i stor grad basert seg på data fra kjønnsbaserte korpusanalyser. Denne forskningen har møtt noe kritikk, da den i likhet med de tidlige sosiolingvistiske studiene, opererer med binære størrelser: «While these social categories are real, choosing this binary opposition as a starting point constrains the set of possible conclusions» (Bamman et al., 2014:138). Bamman et al. (2014:148) mener likevel at «[s]uch an approach may be adequate if the goal is simply to predict gender based on text». Tidlige korpusanalyser konsentrerte seg om bruk av ordklasser (Biber, 1988, 1995; Tannen, 1982). Studiene viste blant annet at kvinner brukte flere pronomen (særlig 1. og 2. person), nektingsadverb og verb i presens enn menn, og at menn på sin side brukte flere preposisjoner, determinativer og attributive adjektiv. På bakgrunn av disse funnene satte Douglas Biber fram en hypotese om at kvinners skrivestil kjennetegnes av «involvedness», mens menn legger større vekt på «information» (1995). Interessant nok viser studiene noe korrelasjon med de etablerte oppfatningene av kjønn, frambrakt av tidlige sosiolingvistiske studier: kvinner ser ut til å tilpasse språket sitt i større grad enn menn. Nyere rettslingvistisk forskning av blant annet tekster i The British National Corpus og av amerikanske blogger støtter også opp om disse funnene (Argamon et al., 2003; Schler et al., 2006). Kvinners «involvedness» synes også å komme til uttrykk i tegnsetting. Simaki et al. (2015) viser blant annet at kvinner bruker utropstegn oftere enn menn, som heller bruker punktum.

I det som er offentlig tilgjengelig av språkekspertens analyse vises det ikke til andre språklige belegg for kjønn. Kjønnsbaserte korpusanalyser, som de nevnt 
over, viser imidlertid at man kan få en pekepinn, om ikke hele sannheten, om avsenderens kjønn på bakgrunn av språklige trekk.

\section{Alder}

Alder har blitt viet mindre oppmerksomhet enn kjønn i forskningslitteraturen, men inkluderes gjerne rutinemessig som variabel i sosiolingvistiske studier, og danner grunnlaget for studier av språkendring gjennom apparent timetilnærmingen, hvor alder brukes for å gjøre antakelser om hvordan en språkendring har utspilt seg. Avsenders antatte alder ble ikke eksplisitt tematisert i tingrettsdommen mot Bertheussen, men språkeksperten diskuterte selv forekomsten av ordet "snut" i rettssaken, og konkluderte med at skriveren må være en eldre person: "Yngre mennesker kjenner knapt nok til ordet «snut». Yngre folk ville ikke ha brukt det”. Helt så enkelt er det ikke. Men en tekst kan si oss en hel del om skriverens alder. I likhet med kjønn, er dette ikke en statisk variabel. Alder er et relativt begrep, og vi kan snakke om både sosial og biologisk alder (Eckert, 1996, 2003; Fløgstad \& Lanza, 2019). I noen samfunn vil en person som har gjennomgått konfirmasjon anses som voksen, mens i andre samfunn (slik som vårt) er videregående opplæring standardisert og voksenlivet begynner først etter slik opplæring. Slike eksterne faktorer har språklige konsekvenser. Ungdomsspråk har f.eks. ulike kjennetegn, samtidig som det er dynamisk, det forandrer seg mer og oftere enn språket til voksne. En persons ordforråd korrelerer ofte også med personens alder og livserfaring. En voksen person vil normalt sett ha et rikere eller mer velutviklet ordforråd enn et barn. Like fullt er det visse ordtyper som gjerne brukes mer av ungdom enn voksne. Banneord brukes ulikt av de over og de under 25, det samme gjør epistemiske adverb og ulike ordklasser. I tillegg er visse skriftspråklige trekk avslørende (alderstypiske feil, fonologisk skriving, osv.); generelle trekk assosiert med grammatisk og leksikalsk utvikling (f.eks. ordforråd; analogi / overgeneralisering; bruk av visse grammatiske kategorier vs. når disse tilegnes (jf. f.eks. passiv; aspekt vs. tempus, osv.). 
Enkelte ganger kan ekstern påvirkning på skriftspråket være avslørende. I den nevnte Unabomber-saken kunne etterforskerne anta at avsender var godt voksen, fordi han fulgte en rettskrivingskonvensjon som var sjelden, men vanlig på 40-/50-tallet, og som dermed plasserte vedkommende i en viss aldersgruppe. Det samme gjorde hans bruk av enkelte ord, som indikerte kunnskap om samfunnsforhold i en viss tidsperiode.

De nevnte lingvistiske faktorene representerer kun et utvalg mulige verktøy, som kunne blitt anvendt i analysen av språket i Bertheussen-saken. Dette er også standardverktøy som burde være selvsagte innfallsvinkler i saker der språklig evidens er involvert.

\section{Diskusjon}

Den 14. mars 2019 ble Laila Bertheussen pågrepet av PST, og den 20. september samme år ble hun siktet for trusler og angrep mot demokratiet etter flere hendelser ved huset hun deler med tidligere justisminister, Tor Mikkel Wara. Retten sa seg enig med aktor i at det er samme person som har utført handlingene i tiltalen, og sendt de etterfølgende forsendelsene. Det er bevist utover enhver rimelig tvil at Bertheussen har utført handlingene i tiltalepostene og laget de aktuelle brevene, sa tingrettsdommer Anniken Nygaard Ottesen. Hittil har vi behandlet enkelte språklige trekk i selve bevismaterialet, diskutert behandlingen av dette materialet, og argumentert for at rettslingvistikken har en rekke verktøy for å gjennomføre mer dyptpløyende analyser.

Selve tingrettsdommen illustrerer imidlertid også en rekke interessante aspekter ved bruken av språklig materiale i rettssystemet i vid forstand. Det mest påfallende er hvor grundig etterforskningen og bevisførselen er innenfor andre områder, slik som elektroniske spor, mens den språklige bevisførselen 
er svært sparsommelig. Ingen av verktøyene som finnes i rettslingvistisk analyse er benyttet på en systematisk måte. Det er ikke gjort rede for hvorvidt brevene er analysert ved hjelp av åpen lingvistisk profilering, eller gjennom sammenligning av tekster. Ei heller er mandatet til lingvisten tydeliggjort. Videre er det ulike elementer som utmerker seg. Det første er den lite akademiske og til dels upresise språkføringen. Språket i tekstmaterialet refereres til som "gebrokkent"; språkeksperten siteres på at "skrivaren er norsk" (i motsetning til norskspråklig; en som har norsk som morsmål eller er flytende i det). Videre refereres det til "idiomatisk norsk", trolig som en motsetning til norsk slik det skrives at folk som ikke har det som morsmål. Det er også påfallende hvordan ulike lingvistiske nivå er vektlagt. Språkeksperten baserer seg primært på leksikalske elementer (f.eks. verbet “tisse”), selv om disse som kjent er enklest å manipulere. I tillegg oppdager man flere språklige avvik (bl.a. feil tegnsetting) i det transkriberte materialet i tingrettsdommen, når man sammenligner dette med de fotostatiske kopiene av språkmaterialet. Forsvaret brukte heller ikke oppdaterte faglige metoder for å underbygge sin kritikk av språkekspertens analyser. Under utspørringen av ekspertvitnet viste Elden blant annet til barneboka Steder å tisse av Svein Nyhus som evidens for at også menn bruker ordet, heller enn grundige korpussøk i databaser over språkbruk. Til sammen illustrerer dette hvordan språk er behandlet overfladisk i denne saken.

Det må påpekes at dette ikke betyr at skriveren (eller en av flere mulige skrivere) ikke kan være en godt voksen, norsk kvinne, slik den språkkyndige eksperten konkluderte. Dette spørsmålet kunne imidlertid blitt behandlet på en langt mer seriøs måte, og gitt bevisførselen mer tyngde, i tråd med faglige retningslinjer. 


\section{“Er dette naturvitenskap?"}

Rettslingvistikken har fortsatt ikke opparbeidet seg samme status som andre nærliggende disipliner, f.eks. rettspsykologien. Til dels kan dette forklares med språkvitenskapens natur, forankret i både naturvitenskap og humanvitenskap, og hvilken vitenskapelig gyldighet humanistiske fag anses å ha. I rettssalen spurte advokat Elden både språkeksperten og skriftgranskeren direkte "Er dette naturvitenskap?”. Implisitt i hans spørsmål ligger ideen om at språkvitenskap ikke er naturvitenskap, og at språklige bevis derfor har begrenset tyngde.

Språkvitenskapen er et særegent felt. Alle er eksperter i morsmålet sitt, og denne intuisjonen alle språkbrukere har om hva som er grammatisk rett og galt, er en av grunnene til at rettslingvistikken har tatt lang tid på å modnes. Et problem i rettslingvistikken er nettopp at alle er språkbrukere, og derfor ikke skiller mellom språk som studieobjekt og som bruksobjekt, i den grad at mange jurister selv tror de er lingvister, som utsagnet til statsadvokat i Bertheussen-saken, sitert innledningsvis, illustrerer. Trenger man egentlig å være språkforsker for å gjøre antakelser om språklig materiale? Der framskritt i en rekke andre fagfelt (f.eks. psykologi) gjerne får konsekvenser for rettspraksis, er dette ikke tilfellet med rettslingvistisk praksis, noe vi også så eksempler på i rettssal 250 høsten 2020, for ikke å snakke om i historien. Det er i liten grad fagfolk som blir bedt om å gjøre rettslingvistisk arbeid.

Som en overordnet problemstilling troner altså manglende rutiner for språklig analyse i norsk rettsvesen, og her var ikke Bertheussen-saken noe unntak. I tillegg til å mangle rutiner, mangler vi presedens i rettssystemet for hvordan de språklige analysene skal vektlegges. Etter vårt syn vil en integrering og formalisering av det lingvistiske aspektet, gjennom ny empirisk kunnskap og teoriutvikling, være avgjørende. Rettslingvistisk kunnskap vil være relevant både for proaktivt politiarbeid (dvs. politimetoder som tas i bruk før et lov- 
brudd oppstår) og reaktivt politiarbeid (dvs. polititiltak i etterkant av et lovbrudd). Rettslingvistiske analyser kan være instrumentelle i arbeidet med å forbedre norsk rettspraksis, ved å «promote justice through the study of language» (Christensen \& Mortensen, 2018:1).

Én mulig metodisk løsning for rettslingvistikken er å bevege seg i retning økt bruk av big data og lingvistiske korpus; ifølge Nini (2019), den nye normen innen rettslingvistisk analyse. Et lingvistisk korpus er en samling av digitalisert språkmateriale, utvalgt etter visse kriterier og tilrettelagt for søking. Dermed er korpusene dit man bør vende blikket når man skal undersøke hvor vanlige ord, setninger og skriftformer er, og hvorvidt de har forandret bruksområde og utbredelse over tid. I Bertheussen-saken ville leksikalske valg (f.eks. "tisse") lett kunne blitt undersøkt i et av de mange korpusene som finnes over norsk språkbruk, og som ligger åpne og tilgjengelige for raske søk, tilpasset sjanger og kontekst. For å kunne si noe om hva som er uvanlig språkbruk, må man ha en fasit på hva som er vanlig. Vanlig språkbruk er også feilbruk, og, som McMenamin (2010) peker på, ofte utilsiktet. Et korpussøk kan si oss noe om hvor idiosynkratiske de utilsiktede språkfeilene er.

Siden språk er dynamisk, individuelt og variabelt, må en korpusanalyse etter vår oppfatning alltid kombineres med en grundig kvalitativ og individbasert analyse, som tar utgangspunkt i oppdatert teori. Bruksbasert teori er her en glimrende kandidat, siden dette er en kognitiv tilnærming til språk hvor individuell variasjon står i fokus (se f.eks. Geeraerts 2006 for en god tekstsamling). Sammen vil disse tilnærmingene kunne fortelle oss noe om den kognitive virkeligheten til taleren, på en langt mer objektiv måte enn ved å konsultere mer begrensede språklige kilder, eller enda verre: lene seg på ren intuisjon. 


\section{Litteratur}

Ainsworth, J. (2009). A lawyer's perspective: ethical, technical and practical considerations in the use of linguistic expert witnesses. I: International Journal of Speech, Language, and the Law 16 (2), 279-291. https://journals.equinoxpub.com/IJSLL/article/view/6609/5930

Argamon, S., Koppel, M., Fine, J. \& Shimoni, A. (2003). Gender, Genre, and Writing Style in Formal Written Texts. I: Text 23 (3), 321-346.

Baker, P. (2014). Using Corpora to Analyze gender. Bloomsbury Publishing.

Bamman, D., Eisenstein, J. \& Schnoebelen, T. (2014). Gender identity and lexical variation in social media. I: Journal of Sociolinguistics 18 (2), 135-160.

Biber, D. (1988). Variation Across Speech and Writing. Cambridge University Press.

Biber, D. (1995). Dimensions of Register Variation: a Cross-Linguistic Comparison. Cambridge University Press.

Chaski, C. E. (2013). Best practices and admissibility of forensic author identification. I: Journal of Law and Policy 21 (2), 333-376.

Christensen, T. K. \& Mortensen, S. S. (2018). Introduction to special issue on Forensic Linguistics: European Perspectives. I: Nordic Journal of Linguistics 41 (2), 129-132. https://doi.org/10.1017/So332586518000112

Christensen, T. K. (2019). Bare vent... Truslers sprog og genre. I: Carlsbergfondet Arsskrift 2019, 78-83. København.

Christensen, T. K. (2021). Joining ISIS? A pragmatic discourse analysis of chat messages in a counterterrorism case. I: Methods and Challenges in Forensic Linguistic Casework. Wiley. 
Dagbladet (2019, 6. juni). Mystiske e-poster: Her tilstår avsender lovbruddene $i$ Wara-saken. Hentet fra https://www.dagbladet.no/nyheter/her-tilstar-avsender-lovbruddene-iwara-saken $/ 71156647$

Diepeveen, A. (2020). "So then the question is whether you are willing to make a statement" - A conversation analytic study of suspect participation in rights communication in Norwegian police investigative interviews. [MA-oppgave] Det humanistiske fakultet, Institutt for lingvistiske og nordiske studier, Universitetet i Oslo.

Eckert, P. (1996). (ay) goes to the city: Exploring the expressive use of variation. I J. Baugh, C. Feagin, G. Guy \& D. Schiffrin (Red.), Towards a social science of language: Festschrift for William Labov (s. 47-68). John Benjamins.

Eckert, P. (2003). Language and adolescent peer groups. I: Journal of Language and Social Psychology 22 (1), 112-118.

Fitzgerald, J. R. (2007). The FBI's Communicated Threat Assessment Database History, Design, and Implementation. I: FBI Law Enforcement Bulletin 76 (2), 6-9.

Fløgstad, G. N. \& E. Lanza (2019). Language contact across the lifespan. Jeroen Darquennes, Joe Salmons og Wim Vandenbussche (red.), Handbücher zur Sprach-und Kommunikationswissenschaft: Language contact. Berlin: De Gruyter.

Gauthier, M. \& Guille, A. (2017). Gender and age differences in swearing: A corpus study of Twitter. I K. B. Fägersten \& K. Stapleton (Red.) Advances in Swearing Research: New languages and new contexts (s. 137-157). John Benjamins Publishing.

Geeraerts, D. (red.) (2006). Cognitive Linguistics: Basic Readings. Mouton de Gruyter. 
Grant, T. (2012). TXT 4N6: Method, consistency, and distinctiveness in the analysis of SMS text messages. I: Journal of Law and Policy 21(2), 467494.

Heydon, G. (2019). Researching forensic linguistics. Approaches and applications. Routledge.

Hjorth, L. N. (2019). Språk, spill og fortellinger i rettssalen. En studie av Orderud-saken [Doktorgradsavhandling]. Universitetet i Bergen.

IAFL (2013) International Association of Forensic Linguists Code of Practice. Hentet 25. februar fra: https://www.iafl.org/wpcontent/uploads/2018/07/IAFL Code of Practice 1-1.pd

Johannisson, T. (1973). Ett språkligt signalement. Gøteborgs Universitet.

Juola, P. (2012). Detecting stylistic deception. I Proceedings of the EACL 2012 Workshop on Computational Approaches to Deception Detection, 91-96.

Labov, W. (1990). The intersection of sex and social class in the course of linguistic change. I: Language Variation and Change 2, 205-254.

Lakoff, R. (1975). Language and Woman's Place. Harper \& Row.

Leonard, R. A., Ford, J. E. R. \& Christensen, T. K. (2017). Forensic Linguistics: Applying the Science of Linguistics to Issues of the Law. I: Hofstra Law Review 45 (3), 501-517.

http://scholarlycommons.law.hofstra.edu/hlr/vol45/iss3/11

Marko, K. (2018). Underlying motivations for the use of linguistic disguise in written English and German threats and ransom demands in an experimental corpus. I: Nordic Journal of Linguistics 41 (2), 205-226.

McMenamin, G. R. (2002). Forensic Linguistics. Advances in Forensic Stylistics. CRC Press. 
McMenamin, G. R. (2010). Forensic stylistics. Theory and practice of forensic stylistics. I M. Coulthard \& A. Johnson (Red.), The Routledge Handbook of Forensic Linguistics (s. 487-507). Routledge.

Nini, A. \& Grant, T. (2013). Bridging the gap between stylistic and cognitive approaches to authorship analysis using systemic functional linguistics and multidimensional analysis. I: International Journal of Speech, Language and the Law 20 (2), 173-202.

https://doi.org/10.1558/ijsll.v20i2.173

Nini, A. (2015). Authorship Profiling in a Forensic Context [Doktorgradsavhandling]. Aston University i Birmingham, UK.

Nini, A. (2019). Corpus analysis in forensic linguistics. I C. A. Chapelle (Red.), The Concise Encyclopedia of Applied Linguistics (s. 313-320). WileyBlackwell.

NRK (2020, 16. oktober) Rettssaken mot Laila Bertheussen. Hentet fra https://www.nrk.no/nyheter/_-samme-type-person-1.15203693

Olsson, J. (2018). More Wordcrime. Solving Crime with Linguistics. Bloomsbury Academic.

Olsvik, E. H. \& Risan, P. (2019). Etterforskning under lupen. PHS Forskning 2019 (3).

Riis-Johansen, M. O. (2016). Balanseganger. En samtaleanalytisk studie av politiavhør av voksne fornærmede [Doktorgradsavhandling]. Norges teknisk-naturvitenskapelige universitet (NTNU).

Sandøy, H. (1996). Talemål. Novus forlag.

Schilling, N. \& Marsters, A. (2015). Unmasking identity: Speaker profiling for forensic linguistic purposes. I: Annual Review of Applied Linguistics 35, 195-214. https://doi.org/10.1017/So267190514000282 
Schler, J., Koppel, M., Argamon, S. \& Pennebaker, J. W. (2006). Effects of age and gender on blogging. I Proceedings of the AAAI Spring Symposium: Computational Approaches to Analyzing Weblogs (s. 199-205). AAAI Press.

Shuy, R. (2002). To testify or not to testify. I J. Cotterill (Red.), Language in the Legal Process (s. 3-18). Palgrave

Shuy, R. (2014). The Language of Murder Cases. Intentionality, Predisposition, and Voluntariness. Oxford University Press.

Simaki, V., Mporas, I., Koumpouri, A. \& Megalooikonomou, V. (2015). Gender Identification of Blog Authors: Do Men and Women Prefer Different Character Unigrams? I: Booklet of papers from the 17th International Conference on Speech and Computer (SPECOM). University of Patras.

Simons, A., \& Tunkel, R. (2014). The assessment of anonymous threatening communications. International handbook of threat assessment, 195213

Stamatatos, E. (2009). A survey of modern authorship attribution methods. I: Journal of the American Society for Information Science and Technology, 6o/3, 538-556.

Svartvik, J. (1968). The Evans Statements. Gøteborgs Universitet.

Tannen, D. (1982). Oral and literate strategies in spoken and written narratives. I: Language 58, 1-21.

Trudgill, P. (1972). Sex, covert prestige and linguistic change in the urban British English of Norwich. I: Language in Society 1 (2), 179-195.

Urbanik, P., \& Pavlenko, A. (i trykken). Securing understanding in a second language: Communication of rights in investigative interviews in the USA and Norway. I R. Blackwood \& U. Røyneland (red.) The Spaces of Multilingualism. New York/London: Routledge. 
Vedeler, L. M. (2020, 21. oktober). Uenige om bruken av ordet tisse. NRK. Hentet fra https://www.nrk.no/kultur/uenige-om-bruken-av-ordet_tisse_-1.15206839

West, C. \& Zimmerman, D. (1987). Doing gender. I: Gender and Society 1, $125-151$. 